\title{
Undecided life: Standards, subjects and sovereignty in compensating victims of the War on Terror
}

\author{
Matthew Allen and Steven D Brown
}

\begin{abstract}
In this article we examine the relationship between standards and subjectivity in the context of compensating the victims of terrorism. We do so by drawing on a corpus of data that features survivor and bereaved accounts of two twenty-first century terrorist attacks. We investigate the distressing period in which compensation claims remained undecided, in some cases for over seven years after the attacks, and how the process of assessment acts as a 'technology of desubjectification'. To articulate this we turn to Giorgio Agamben's notion of 'undecidability' in which the ambiguity between life and law is used by governing authorities to suspend and blur key distinctions such as what lies inside or outside the juridical order. In particular we aim to clarify that, in the context of claiming compensation for an act of terrorism, being undecided is a means by which the state maintains claimants within a 'holding category' of victimhood that prevents their recognition as a political subject. We conclude with some reflection on how technologies of desubjectification operate within an 'age of austerity'. Critical psychology need to update its neoFoucauldian understanding of subjectivity to include the production of 'cranked subjects'.
\end{abstract}

Key words: Terrorism, London bombings, Sharml el Sheikh bombings, compensation, Michel Foucault, Giorgio Agamben, undecidability, biopolitics, subjectivity.

\section{Introduction}

In his essay Lives of Infamous Men, Michel Foucault reflects on the pre-history of modern French juridical practices as it is exhibited in the petitions written to the sovereign around the turn of the seventeenth century by ordinary citizens imploring him to intervene against the criminality, abuse or libertinage of their fellow citizens and family members. The art of writing these petitions effectively, Foucault notes, lay in a skill at transforming 'petty sufferings' into noteworthy acts that warranted the attention of the sovereign (or rather, his proxies), in order to provoke the mobilisation of his enormous powers down upon the head of the individual specified. Foucault sees in this short-lived practice a critical moment when the Western tradition of 'confessing' everyday transgressions became a matter of writing and recording rather than simply expressing and absolving. If longstanding Christian practices had 'obliged the quotidian to enter into discourse' (Foucault, 2002: 174), the petitions to the King constituted a new relationship between the description of individual behaviours and the assumed normative conduct of the everyday lives of the 'masses':

An unending hum began to be heard, the sound of discourse that delivered individual variations of behaviour, shames, and secrets to the grip of power. The commonplace ceased to belong to silence, to the passing rumor or the fleeting confession. All those ingredients of the ordinary, the unimportant detail, obscurity, unexceptional days, community life, could and must be told - better still, written 
down. They became describable and transcribable, precisely insofar as they were transversed by the mechanisms of a political power. (Foucault, 2002: 169)

The 'unending hum' of which Foucault speaks is the ceaseless communication of information about individuals into the relays of power. Ordinary people and their lives become inscribed as written documents, as matters of record out of which 'the social' is woven. And yet once the sovereign has been replaced as an addressee of this speech by a 'fine differentiated, continuous network, in which the various institutions of the judiciary, the police, medicine and psychiatry operate hand in hand' (p.171), it is only a short step for the aggregation of these descriptions of the everyday to be handled by 'the efficient but colorless categories of administration, journalism and science' (p.172).

This essay, along with the two documents on Pierre Rivière and Herculine Barbin, has a pivotal place in Foucault's thinking of the relationship between subjectivity and standards (see Foucault 1978; 1988). It charts how individual lives became 'made into 'matters', into incidents or cases' (p.172). A case is a formal description of a life that interprets episodes, acts and character through the codes and norms of institutional discourses. The idea that any life, not merely that of remarkable or infamous women and men, can be considered 'case-worthy' marks the moment when 'the masses' lose their invisibility. Anyone, at any time, can become an object of concern for the state because of the requirement to ceaselessly speak of oneself in the course of routine engagement with social welfare, medicine, legal and pedagogic practices. These practices deploy abstract representations in forms such as measures, typologies, process maps etc, as standards against which this speech is 'describable and transcribable', and as the basis for making judgments. Hence, for Foucault and his followers, subjectivity is formed through contact with and in anticipation of the diverse institutional practices that make up the modern state. The memorable image of the 'panopticon' that Foucault (1977) provides, acts to anchor this theorising of subjectivity and subjectification: continuously visible, yet not knowing if one is at any moment currently case-worthy, the subject's relationship to her or himself is mediated through their understanding of the categories and standards deployed in the networks and apparatuses of power.

Critical Psychology has for some time been drawn towards this Foucauldian account of subjectivity because it clearly positions formal psychological practices as central political players in the shaping of modern subjectivity ${ }^{1}$. In the highly influential Changing the Subject, Julian Henriques and colleagues use the notion of subjectification to argue that the production of normative accounts of personality, development, emotion etc within psychology serves a neoliberal political agenda. Fellow traveller Nikolas Rose spend much his earlier career in sociology working up a genealogy of the emergence of psychology in the UK as a distributed apparatus of power embedded within the nineteenth and twentieth century British state (Rose, 1985; 1989). This earlier work provides the context in which lan Parker's voluminous investigations and critiques of the 'psy-complex' are set (see, for example, Parker 2014; 2007).

Despite the many achievements of this fascinating body of work, our argument in this paper is that it is time to rethink the purchase of a Foucauldian account of subjectification in 
modern psychological practices. Our reasons for making this call differ from those of either Hanna (2013), who argues for a greater focus on practices of resistance within projects of self-making, or Hojgaard and Sondergaard (2011), who point to a relative neglect of the extra-discursive sociomaterial aspects of technologies of subjectification. We argue that psychology in an age of austerity is less concerned with differentiating individuals within normative frameworks, than it is with a project of dedifferentiation, where persons are committed to ill-defined and elastic 'garbage categories' that warrant them as undeserving of specialised attention. For example, the UK government's recent use of psychometrics as part of a 'nudge' strategy run by the British Behavioural Insights Team, has the simple aim of removing citizens from the category of 'jobseeker' (along with its associated welfare benefits). This is done under the guise of a test that purportedly gives the recipient important information about their personality and motivations. However, as Cromby and Willis (2014) demonstrate brilliantly, this information amounts to little more than an exhortation to seek out employment opportunities rather than remain a burden upon the state.

If Foucault's insight was on the emergence of 'case-worthiness' as the basis of subjectivity, then what we see now in social welfare practices in the UK is a tendency towards the extended suspension or disqualification of persons as 'cases'. In fact, the categories and standards through which cases are often constituted are designed to allow for a suspension of judgment. The rise of the diagnostic category of 'Personality Disorder' (and its wide variety of 'Borderline' affordances) in forensic psychiatric practices, for example, is associated with a tendency to treat mental health service-users as unsuited to expensive hospital based treatment due to the intrinsic personality factors which label them as antisocial and resistant to change (see Cromby, Harper and Reavey, 2013). This broad and illdefined category appears to be a way of discounting the specificity of individual lives and experiences and as a consequence deferring the need for specific or tailored intervention. If subjectivity is shaped by the making of life into 'matters' and 'incidents', then a life lived with such a diagnosis is done under perpetual suspension, mediated by a standard that erases and dilutes the contours of experience.

We will elaborate our argument by working through the example of compensating victims of terrorism. Compensation processes operate through a network of standards and categories through which the state recognises subjects who make claims upon it. Engaging with these processes requires persons to offer up their experiences of loss and injury in the hope of some form of reparation that will allow them to make sense of the events in which they have been caught. It would be reasonable to expect that a victim of terrorism would be accorded the status of a political subject. However, as we will show, compensation mobilises categories that tend to fragment and degrade the quality of experience, and which actively prevent persons from engaging in effective self-formation. In the following sections, we first of all describe how state responses to terrorism provide a general model of 'exceptionality' in the use of standards that render them as 'technologies of desubjectification'. We then offer a brief genealogy of compensation practices in the UK which provides the context for an analysis of the particular experiences of three victims of terrorism with state reparation. 
The data that underpins our discussion here is part of a broader corpus of interviews and focus group material on remembering the 2005 London Bombings. This material was collected as part of Strand 2 of the research project Conflicts of Memory: Mediating and Commemorating the 2005 London Bombings ${ }^{2}$. Strand 1 of the project undertook linguistic analysis of the television news reporting on the bombings, adopting multimodal discourse analysis (Kress, 2000), to identify the emerging linguistic patterns of 24-hour news reporting3. Strand 2, which supplied the data presented here, concentrated on gathering ethnographic material to illustrate how remembering the bombings collected social relations. In December, 2010, the project conclusions were presented at a one-day symposium in Nottingham 4, in 2011 a special issue of Memory Studies delivered the project findings (see, Allen and Bryan 2011). It was intended that both strands of data gathering would be mutually supportive. For instance, participant recruitment for Strand 2 was informed by the Strand 1 survey and analysis of the media coverage of $7 / 7$ over a twelve-month period for identifying key 'memory choreographers' (Conway 2010) associated with the bombings. In all, Strand 2 approached twenty-five individuals for interview using publically available contact information. Semi-structured interviews were conducted with survivors, bereaved relatives, activists, emergency and psychological service personnel and the memorial designer. Interviews usually lasted around one hour, though some ran longer where the participant indicated their willingness to continue. All interviews were recorded and transcribed. The transcripts were coded using NVivo 8 following conventions in discursive psychology and conversation analysis strands of discourse analysis (Willig, 1999; Wooffitt, 2005). A peer-reviewed coding framework was established after an initial reading of the data corpus. Our analysis proceeded by identifying emergent themes within each code. The following discussion draws upon our analysis of interview data coded to the theme "justice". In keeping with the conceptual framework that we have introduced above we have organized the empirical material to illustrate the experiences of three people for whom becoming formally case-worthy was not straightforward.

\section{The terror of standards}

The first decade of the twenty-first century was marked by a series of violent conflicts related to the so-called War on Terror. This period witnessed attacks on major urban centres including New York, Jakarta, Madrid, London, Sharml el Sheikh, Delhi and Mumbai as well as the military invasions and occupations of Iraq and Afghanistan by a US-led coalition of governments. These conflicts disrupted conventional ideas about war, as fought between opposing sides, mostly because of the ideological and political framing of the combatants. The city attacks, typically carried out by small groups working within global networks, were characterised in Western media, political and juridical contexts as acts of terrorism, whereas the occupations in the Middle East were ideologically linked to an ongoing war on terrorism. Often dubbed the post-9/11 era, the far-reaching effects of the aftermath of the attacks on the World Trade Center have been discussed in terms of international relations (Cox, 2002; Buzan, 2003), media representation (Hoskins and O'Loughlin, 2009, 2013), security and governance (Anderson, 2010; Dillon, 2007), public policy (Bossong, 2013) and cultural politics (Fisher and Flota, 2013; Puar, 2007; Silk, 2013). 
A commonly held view is that the terrorism of the post-9/11 era is somehow paradigmatically different from the acts of terror that preceded the War on Terror. However the political semiotics that surrounds the application of the term terrorism are complex. As Chomsky has argued:

The term "terrorism" has come to be applied mainly to "retail terrorism" by individuals or groups. Whereas the term was once applied to emperors who molest their own subjects and the world, now it is restricted to thieves who molest the powerful - though not entirely restricted: the term still applies to enemy emperors, a category that shifts with the needs of power and ideology. (2002, p. vii)

A kind of inversion is at work here, where the term 'terror' has been dislocated from its previous reference point of state's power over its own subjects to its use as a blanket term for acts against the state. At the same time, the conception of sovereignty that lies at the heart of how the state is traditionally conceived in political theory has undergone a parallel inversion. Giorgio Agamben's (2005) account of the 'state of exception' captures this well. His work on sovereignty commences with the view that the most radical expression of sovereign power involves suspending a constituted juridical order to impose exceptional conditions upon the governance of life. Historical examples of this include the use of martial law and emergency powers to respond to an impending threat of annihilation. Such cases marked the limits of legal systems because the emergent threat forced the introduction of new standards. This entails an ethical problem that has vexed political philosophers for centuries, namely whether or not in exceptional circumstances it is justifiable to suspend the rule of law for the preservation of sovereignty. However Agamben argues that modern constellations of sovereign power generally circumvent this ethical juncture because, since World War I, a pattern of government has emerged that involves enacting legal standards that are predicated on and productive of a continuous state of exception. This means that the exercise of sovereign power is no longer framed by the ethical terms set out above, which are only resolved by a decisive act that breaches the existing juridical order of legal standards. Rather, sovereign power is already at work when exceptional rulings can be articulated by reconfiguring the existing standards of the rule of law. The example that Agamben uses to illustrate this point is worth citing in full:

The USA Patriot Act issued by the US Senate on October 26, 2001, had already allowed the attorney general to "take into custody" any alien suspected of activities that endangered the national security of the USA; however, as per the Act, within seven days the alien had to be either released or charged with the violation of immigration laws or some other criminal offence. What was new in President Bush's order is that it radically erased any legal status of the individual, thus producing a legally unnamable and unclassifiable being. Those captured as terrorists in Iraq did not enjoy the status of POWs as defined by the Geneva Convention, they did not even have the status of persons charged with a crime according to American laws. Neither prisoners nor persons accused, but simply "detainees", they are the object of pure de facto rule. They are removed from the law by taking permission of the law itself. (Agamben, 2005: 4)

The Patriot Act exemplifies Agamben's view of contemporary sovereign power as simultaneously both including and excluding the lives that threaten its persistence. It does 
so by imposing exceptionally violent terms on subjects that exist as reconfigurations of existing standards in international law i.e. detainees are reconstructed prisoners that are subject to exceptional conditions, which in extreme cases this included reports of torture. In this way, standards emerge that can be indexed against existing precedents but which also allow degrees of mutability without an absolute departure from the existing rule of law. This marks a stronger hold over the gulf between standards in code and standards in practice, or in legal terms, the law de jure and de facto. Sovereign power enacts legal standards to further blur the ambiguity between life and law.

Agamben's work is central to the emerging 'biopolitics' paradigm within social and political science (see Reid, 2006; Terranova, 2009; Clough and Willse, 2011; Väliaho, 2014). This field takes its point of departure from Foucault's conception of the modern state as principally concerned with the administration of the population (or 'social body'), expressed in terms of life and living labour (Foucault, 2007; 2010). Crucially, biopolitics involves a shift away from a concern with individuals and subjectification, and towards a fragmentation of persons as living beings that can be known and managed in multiple, partial ways (Dean, 2010; 2013). For example, a person can be simultaneously considered in terms of their 'wellness', their aptitude for particular kinds of labour, their capacity to function in a community, their 'emotional intelligence' and so on, without there being any sense of a coherent subject linking together these various attributes. In this way the state withdraws the status of political subjects from citizens in anything other than the most basic sense (i.e. the right to vote in the media spectacle of national and local party politics). The state of exception that can be so clearly seen in the War on Terror becomes the general model for all 'biopolitical' governance.

This brings us to the paradox that is at the heart of the relationship between subjectivity and standards within the biopolitical modern state. Michael Dillon observes the 'radical ambiguity' in which 'western societies themselves are governed by terror in the process of trying to bring terror within the orbit of their political rationalities and governmental technologies' (2007: 8). Because the state refuses to recognise the terrorist as a political subject, they are driven by the increasing problematic search for better knowledge over the partial overlapping attributes through which this de-subjectified actor can be managed. This takes the form of subjecting the aspects of life that already fell within the orbit of their juridical control to increasing specification and governance (e.g. waste management in train stations, liquid consumption in airports, public surveillance, the circulation of so-called terrorist literature and images). The 'radical ambiguity' of this project is that in trying to make terror governable, the state is led to make ever more excessive and exceptional efforts to manage the minutiae of the sociomaterial fabric of its territory.

Standards are typically thought of as protocols and procedures designed to enhance the interoperability of devices, organisations and practices. They are normally treated as disappearing into the infrastructures that they govern (Bowker and Star, 2000). But within a 'state of exception', standards tend to become more elastic and subject to rapid reconfiguration, whilst still maintaining a relationship to the (legal, political, moral) codes from which they are drawn. As such, the inherent 'violence' within standards, which arises through their imposition of convergence, division and erasure within categories (see Bowker 
and Star, 1999) is felt more keenly, especially at the level of the mundane governance of society (Woolgar and Neyland, 2013). For example, the much discussed prosecution of Paul Chambers, who tweeted a 'joke' message about 'blowing' a UK regional airport 'sky high', demonstrated how new standards for what constitutes 'menacing' communication could be rapidly assembled from existing legislation written some time before the medium used came into existence.

The experience of standards in cases like this is then considerably different from the Foucauldian model of subjectivity. In that model, our subjectivities are shaped by the anticipation of the categories and typologies that might be relevant to our thoughts, feelings and actions and to those of others around us. For example, the patient who deliberates the consequences of telling their doctor about their suicidal thoughts, the parent who prepares for a meeting at a school to which they have been summoned to discuss their child's behaviour, the worker who creatively adjusts their outputs on their performance review. But within the 'exceptional' use of standards, there is little clarity over which standards might apply on any particular occasion, nor on how they might be specifically worked out. Moreover, outcomes are more likely to apply to particular 'bits' of the person rather than attach to them as an overall subject. These are what Deleuze refers to as 'dividualised' or 'dividual matters' (1995: 182). For example, the doctor will be concerned with the management of these particular symptoms rather than the overall welfare of the patient, the school with test results, attendance or behaviour during school hours instead of the child's developmental trajectory, the company with overall performance rather than the personal relationship of the worker to the business. It is this sense that the exceptional use of standards supports a 'post-psychological' notion of subjectivity.

We will now elaborate the argument further by exploring how UK based victims of terrorism have experienced the exceptional use of standards in relation to compensation for their injuries and losses, and the dilemmas this has created for their individual projects of selfmaking. To set the scene, we first offer a very compressed genealogy of compensation practices, which demonstrates how subjectivity has been increasingly eliminated from the conception of the injured person.

\section{Compensation and its discontents}

Compensation usually takes the form of financial reparation for some personal loss or injury. Within a retributive model of justice, compensation relies upon establishing an injured victim and a culpable guilty party. However, the reliance on a financial settlement of moral issues inevitably gives rise to the problems of the irreducibility of subjective qualities such as guilt and forgiveness to monetary values. The challenging aspect of reparation in this regard, as Graeber notes, is a matter of equivalences, since 'no one presenting such compensation would ever be foolish enough to suggest that any amount of money could possibly be the "equivalent" to the value of someone's father, sister, or child' (2011: 234). Reparations involve the dangerous possibility that the guilty underpays or the victim overvalues their injury. It is this tension that drives the standardisation of compensation in criminal justice. 
The codification of compensation in English law involves a long and complex history that has its ancient roots in Roman law (Musson, 2001: 41); we will not survey this history in full here, instead we briefly note two loci, work and war, that shaped the contemporary standardisation of compensation practices in Britain. Worker compensation dates at least to the Sumarian law of Ur (circa 2050 B.C), which decreed monetary compensation for worker injuries (Guyton, 1999: 106). This practice became systematic in English law with the development of common law during the medieval period, which provided the legal frameworks for the industrial revolution (ibid.). A series of statutes ${ }^{5}$ introduced during the $19^{\text {th }}$ century ushered the formation of a new legal construct that fostered new experiences of life at work, namely the industrial accident (Burnham, 2010). To be compensable for an industrial accident claims had to comply with three criteria: 1 . The claimant was not responsible for the injury (contributory negligence), 2. A colleague was not responsible (the fellow servant rule) 3 . The employer did not provide appropriate safety measures (assumption of risk). While these conditions classified what would count de jure as an industrial accident, the ambiguities of negligence, responsibility and risk de facto were typically loaded in favour of the employer against the worker. Nonetheless, successful claimants could expect monetary awards based on a standard system of calculating loss of earnings and impact on potential future earnings.

This arbitrary system condensed more complex societal issues such as whether or not the worker had the freedom to be otherwise employed and thus avoid injury in the service of the industrial division of labour. Thus worker compensation established a system of equivalences that allowed complex issues of individual, collective and moral accountability to disappear into its operation. Today in Britain, with a few exceptions, employers are required by law to purchase Employers Liability Insurance. This led Bartrip and Burnam (1984) to conclude that worker compensation was, ironically, antecedent to both the development of a private insurance market and the modern welfare state. For our purposes it is significant that, in standardising practices for resolving conflicted relations between workers and employers, the grammar of economics formally prevailed over psychology. We do not mean to suggest that psychology did not contribute powerful rhetoric to the litigation of industrial accidents (see, for example, the decisive role of psychiatric discourses in the outcomes of railroad spine cases, Harrington, 2001). However, worker compensation prioritises transactional rather than dialogical reason to deliver retributive justice, which means its standardised system of equivalences formally eclipses opportunities for workers to engage in subjective terms with those they might consider responsible for their injury.

In contrast, since World War II the development of international standards for compensating the victims of war has reflected a restorative approach to justice. This involves a de jure shift from punishing the guilty to responding more directly to the needs of the victims. Compensation to this end is instrumental for mediating the restoration of long-term peace following violent conflict. The Geneva Conventions (1949) and the Additional Protocols $(1977,2005)$ are key precedents in the standardisation of compensation according to international humanitarian law. Unlike worker compensation, which focuses on individual damages and losses, these treatises also codified the use of compensation to eliminate unjust gains. In theory this requires addressing issues that exceed the parameters of an 
arbitrary system of injury and monetary equivalences; as Imre summarises 'compensation may be exacted but only on the condition that a polity's populace can still participate in fundamental human goods. Perhaps most importantly, there must be a concerted effort to rehabilitate the vanquished polity and its infrastructure' (2013: 222). This precludes, for example, imposing a poll tax on the people of Afghanistan to compensate the US-led coalition of armed forces for their material losses during the occupation their country (Orend, 2002: 49). Compensating the injuries of war, in accordance with international law, means soldiers on both sides can be held accountable for war crimes whilst a distinction is held between civilians, soldiers and leaders. These principles go beyond the transactional logic that we observed in worker compensation and situates procedural justice, in principle, as a potential platform for engaging in a subjective work of restoration. However this platform governs compensation, and dialogue, at the level of collectives and there remain issues of how international standards are implemented in domestic courts for determining and dealing with 'case-worthy' lives (Gillard, 2003).

These advances in common and international law are important precursors to the standardisation of compensation in British criminal justice. A key development here was the inauguration in 1964 of the Criminal Injuries Compensation Board. Later, in 1972, the enactment of the Criminal Justice Act introduced the compensation order for injury and loss or damage of property (Ashworth, 2005: 298). The effects of this were long-term changes in attitudes toward interpersonal violence mainly because assault became compensable as a criminal matter (Williams, 2005). Changes in parliament, including the introduction of the Criminal Injuries Compensation Act in 1995, caused significant reform in how claims were processed, in particular the calculation of awards would previously use the sums awarded in civil cases as a guide, today this is governed by an arbitrary index set by parliament ${ }^{6}$. In 1996, to reflect these changes, the Criminal Injuries Compensation Board was restructured and renamed the Criminal Injuries Compensation Authority (CICA). It was this authority that was responsible for processing the compensation claims following the London bombings. A government report on CICA raised the following criticism:

Some survivors have said that they found the process of applying for compensation from the Criminal Injuries Compensation Authority (CICA) bureaucratic, slow and distressing. This was partly because the Authority had to check that individuals had actually been present at the incidents (achieved through a police report) and that their injuries were of the severity claimed (achieved through a medical report) before making a payment. (Reid and Jowell, 2006: 8)

The problem here is that survivors of the bombings found that simply describing their experiences was not sufficient to elicit a response from the state. Their descriptions and transcriptions had to be compared with numerous other reports and undergo an extended cross-checking. But the process of having to repeatedly offer up accounts of their stories was experienced by survivors as an obstacle to the work of self-reconstruction in which they were engaged. This was exacerbated by the condition of using a standard application form ${ }^{7}$. This compelled claimants to reconstruct the past in terms of preferred stories and reflect on their relation to themselves in calculable terms such as loss of earnings and cost of accessibility aids and adaptations. Then, as claims remained undecided, the process 
frustratingly delayed the possibility of transforming claimants into subjects that stand in relation to the act of terrorism as recognised by governing authorities i.e. a survivor or bereaved relative. Thus a distressing part of claiming for compensation was the failure of the application process to furnish survivors with the material they required to subjectively work upon themselves, their identities and relations to others.

The shortcomings of compensating the victims of the London bombings reinforced a broader call for reformations in the administration of domestic and international criminal justice. In 2012 reforms of CICA included new eligibility criteria related to UK residency and unspent criminal convictions as well as calculating loss of earnings at the rate of statutory sick pay regardless of the claimants actual losses. From an international perspective, in 2011 the United Nations responded to the issue of compensating for terrorism by publishing a handbook with the aim to aid its member states in developing and implementing 'programmes of assistance and support for victims of acts of terrorism within their respective criminal justice systems' (UN, 2011: v). Despite these recent developments, when compensation and terrorism have been addressed together it is almost exclusively from a legal perspective (Bottigliero, 2012; Walker, 2011), this means that the subjective dimension of becoming a claimant and living with consequences have been largely ignored. This is equally true of the psychological literature on legal proceedings more generally. For instance, therapeutic jurisprudence, a branch of victimology, has studied the effects of criminal justice systems on mental health and emotional recovery (Simon, 1995; Wexler and Winick, 1996). Considerable attention has been given to how victim satisfaction with the procedural outcome affects emotional wellbeing and cognitive states (see Kunst, et al., 2014). For example, in a comparative study of adversarial and inquisitorial structures of criminal justice, Laxminarayan found that contact with a judge in the Netherlands, when compared to Australia, was 'predictive of a less negative impact on psychological effects' (2014: 781). The failure to properly address the broader politics of criminal justice frames victims as consumer-citizens, where a logic of choice prevails over a logic of care (Mol, 2008). For us, a psychological account of participation in criminal justice cannot be so easily divorced from the highly charged political context in which making a claim takes place. If public expressions of grief signal that a life counted (Butler, 2009), then compensating the victims of terrorism involves making a politically charged statement about how much that life counted. If, for the most part, criminal justice involves a formal separation of legal and psychological aspects of compensation in order to economically settle an injury or death then a post-psychological curiosity would reject this bifurcation of life and law, and the data featuring in the next section compels us to call the desubjectifying effects of standards into question. Here we can offer a close analysis of the rub between the political context of exceptionality and distressing experiences of being denied the status of case-worthy lives.

\section{Transforming the subjects of terror}

In this section we gain insight into the desubjectifying experience of compensation practices through a close analysis of three sets of accounts. The first series of extracts are drawn from an account written by a survivor of the London bombings reflecting on his experience of the media representation of himself and others as claimants of compensation. The second data 
sequence features interview extracts that present a father's account of his experience of repatriating his son's body after he was killed in the Sharm el Sheikh bombings. The final series of extracts are taken from an interview with a survivor who discusses their own relation to "victimhood" and other subjects of the London bombings.

The media representation of the criminal justice response to terrorism had a significant role in shaping experiences of compensation standards. For example the legal response to the London bombings gained considerable attention in British news media when journalists criticised the sums of financial support received by victims and bereaved relatives (Bennett, 2006; Mansey, 2012), the legal rights of perpetrators and victims (Helm et al., 2012), and the systemic failings of the compensation scheme (BBC, 2010). Perhaps the most controversial aspect of compensating the individuals and families who were affected by the London bombings was the lengthy duration involved in processing claims with reports of cases unresolved over seven years after the attacks (Randhawa, 2012). In this sense, the standards applied appeared to actively suspend rather than resolve the cases, meaning that persons involved in the events lived with the 'holding category' of 'victim' in the absence of a procedure that might have allowed them to experience some sense of reparation. As we shall see, the category of victim is one that ultimately inhibits rather than facilitates efforts at managing the personal impact of injury and loss.

The series of extracts that follow offer insight into how the mediatisation of compensation represented a distressing aspect of encounters with standards after the London bombings. The subsequent remarks are taken from an academic article written by John Tulloch (2008: pp. 454-455) in which he reflects upon his subjective experience of risk after he survived the explosion on the train at Edgware Road Station. On the media coverage of the London bombings compensation he writes:

In the media after $7 / 7$, an insurance risk discourse, based on calculative techniques (and comparative analysis with US government payouts after 9/11), was being blended with antigovernment political rhetoric in a populist media campaign around the 'injustice' of compensation to victims after $7 / 7$.

Tulloch identifies the effects of an insurance risk discourse; the antecedents of which lie in the arbitrary system of equivalences that we observed initially governed the compensation of workers. The media criticism of the injustice' of such a calculative logic lent itself to an anti-governmental political rhetoric. However, for Tulloch, this critique was ineffective since it was disconnected from people's lived experiences of compensation. In the next extract he goes on to detail some personal cases of individuals that received specific media coverage:

the most sustained media analysis I read of the compensation issue relating to the victims of $7 / 7$, by Rob Blackhurst in the Financial Times. His piece, 'Add insult to injury,' quotes as symptomatic the mother of two young children, saying that she felt abandoned and offended by the government's tiny $f 5,500$ 'price tag' on her husband's death in the bombing on the Circle line at Aldgate; and he quotes Danny Biddle (who lost both his legs, one eye, and his spleen in my carriage at Edgware Road), responding to his compensation report: 'Head burns - minor visible disfigurement $£ 2,000$; Face-moderate disfigurement, $£ 5,500$; Necksevere disfigurement $£ 16,500$. . . How can they say you get blown up, you almost died, you 
had all these injuries, but we're only going to compensate you for three of them? These are parts of my body we're talking about-this ain't the Argos catalogue' (Blackhurst 2006: 17).

This extract makes it clear that, in contrast to the popular media claims, the injustice of compensating the victims of 7/7 was not limited to its fiscal inadequacy when compared to the US payouts after $9 / 11$. The media coverage that Tulloch describes as the most sustained analysis takes particular issue with the calculability of life and injury. The standard system of awards created frustration and offence toward the commensurability of injury and death, which invited comparison to the composition of a high street retail catalogue ('This ain't the Argos catalogue'). The case of the mother reported here shows that the distress of compensation is not simply limited to a badly calibrated system of equivalences. The reference to feelings of abandonment suggests that what is really problematic is the failure of compensation standards to recognise the victim as a whole subject. The monetary reparation is experienced as form of erasure of the man's status as a husband and father, a person defined by their relationships and conduct, not simply their 'bare life' (cf. Agamben, 1998). The mother's offence stems from a sense that the award represents a 'price tag' by means of which governmental authorities buy themselves out of engaging with the complex intersubjective processes that follow bereavement, and with the work of making sense of the husband's death and its place in the complexities of contemporary politics. In short, the compensation processes both desubjectify the life of the man and serves as a significant obstacle to the emotional and relational work that his bereaved relatives need to commemorate and carry forward the meaning of his life and tragic death. This theme extends into the final extract in which Tulloch turns to reflect on the coverage of his own compensation case:

My own case is also discussed in the Blackhurst article, and my personal take on compensation at that point reported. 'Tulloch is diffident on the subject of his own compensation, "there are people who have a far better case than I do," but a recent incident with a compensation cheque has made him fear that his condition might be worse than he previously thought ... [H] now thinks the tabloid campaign [on compensation] might have been right' (Blackhurst 2006, p. 20). The tabloid campaign Blackhurst is referring to here was the News of the World one of October 2006, as part of which I was subjected to a newspaper beat-up of my own compensation case after I initially declined to be interviewed, and then did give an interview because of a highly subjective sense of empathy with another victim who had lost both her legs. In this case, my emotive/intuitive feeling for another terror victim, whom I had never met but who-like Biddle-was the same distance from the blast as myself, and like him also had suffered horribly, was mobilised for a populist campaign against Blair by a newspaper routinely engaged in market share competition. Later I drew on the calculative rationality of my PTSD psychologist's cognitive behavioural therapy to understand and maybe self-justify that rather embarrassing and upsetting experience.

In this extract we observe how the force of standards come to bear on fragmenting subjectivity. Tulloch had initially felt the claims of others were "better" than his own until an "incident with a compensation cheque" made him think his case was more severe. The terms of the incident are not revealed but the later reference to PTSD therapy suggests the compensation cheque may have exacerbated the trauma of surviving the bombings. This raises the emotional and affective qualities of even the most mundane aspects of the 
compensation process, in this case the medium of payment. Underpinning Tulloch's reported remark that others had better cases for compensation is a logic that frames physical and psychological injury as comparable. There is a clear relationship here to the formal processes by which victims has to apply for compensation. Their claims were 'dividualised' into specific matters - injuries, severity, location, time. Evidently one effect of calculating injury in this way is that one's own injuries become commensurate in terms of the injuries of others, regardless of the nature and severity of injury. The extract indicates that Tulloch developed his own calculus for governing his emotive and intuitive feelings toward other victims and that this too can be traced to the terms of the same government report. Recall that the Authority also had to verify, by reference to police reports, that people had been 'present at the incidents'. The police reports included diagrams of the train carriages that mapped the locations of victims in relation to the cartography of the bombings ${ }^{8}$. It is not surprising then that distance became a significant modulator of Tulloch's subjective relation to other victims. Finally, we note that the 'calculative rationality' of cognitive behavioural theory afforded Tulloch with the subjective resources he required resolving and even justify what he describes as an embarrassing and upsetting episode. Once again we can see that the distressing aspect of the compensation process was its inadequacy in affording claimants with opportunities to constitute themselves as whole subjects. To phrase this in the terms previously presented we can say this is a failing of compensation standards that engendered a retributive rather than restorative model of criminal justice.

The next sequence of data outlines Peter Fulham's struggle to return his son's body to their hometown in Britain. Matthew Fulham, Peter's son, was killed in a bomb explosion on the eve of his 18th birthday during a family holiday in Sharm el-Sheikh. In the first data extract Peter comments on the delay in repatriating Matthew:

Matthew, you see, although he was killed in July, it wasn't until September that we got his body back, which was horrendous [Peter Fulham, interview]

Matthew was killed in Egypt on 23 July 2005 but his body was not repatriated until September of that year. Repatriating bodies, especially after violent conflict, become highly politicised and immensely contingent as they are subject to ritual and organisational practices (Allen, 2014: 76). One aspect of that contingency in this case arises from the displacement of agency from the deceased and his family to institutional actors who intervened upon and organised his body in objectifying ways. The conditions that Peter experienced as 'horrendous' exist partly in the way in which Matthew became a repatriating body subject to standards. This becomes more explicit in the next extract, where we are introduced to the gulf in governmental responses to Matthew's death that left the family with no obvious course of action:

The insurance companies had said it was an act of terrorism, there's a little line that excludes acts of terrorism. The [British] government said well you weren't injured in Britain you'd have to go and sue the perpetrator, who'd killed himself. We tried Egypt, Egypt said no, it was force majeure. There was nothing we could have done. [Peter Fulham, interview] 
At least three constellations of standards impinged upon Matthew's repatriation. His body became an object of accountability and the violence of standardisation is seen immobilising the body-object in Peter's account as he recalls the categorical refusal of accountability that each author tendered (Matthew's death was the result of terrorism, non-domestic injury and force majeure). Each ruling has its own filiation to the standards of international law, and each ruling has the effect of reconfiguring Matthew's body first as terrorist victim, then offshore corpse and finally an unforeseen circumstance. At a more fundamental or 'horrendous' level, the impasse created by accountability meant 'there was nothing [that the family] could have done' to assuage the delay in Matthew's repatriation. The 'horror' originated in a collapse in the interoperability of criminal justice systems. The immobilising effects of this lack of interoperability reflect the situation that Agamben (2005) has called the "threshold of undecidability". This threshold describes the political use of the ambiguity between life and law in such a way that suspends and blurs key distinctions such as what lies inside or outside the juridical order. Here Matthew's case demonstrates how a discordant nexus of standards heightened the grief around death, a process, by reducing the body of the deceased to an object that presents an organisational problem in need of negotiating the networks of bureaucracy that make up the authorities in question. The undecided governance of Matthew's death, by at least three institutions, limited the family's freedom to mobilise his body and engage in memorial rites, subjecting them to a 'horrendous' delay, in turn reconstituting their lives as subjects of sovereign power.

In the final extract we can observe how the governance of Matthew's case was exacerbated by the public response to the Sharm el Sheikh attacks in comparison to the London bombings which led the family to feel alienated from the bereaved of other terrorist attacks and categorised them as victims of non-domestic terrorism:

They're having this remembrance about 7/7 and yet Turkey, Sharm el-Sheikh, Bali, the other Egypt bombings the Saudi Arabia stuff, nothing, no one ever says anything. It was like there was a blip, there's another story to look at, oh, there's some interesting images, now let's go back to our back yard again. And I guess you can understand that, but it still kind of hurts. [Peter Fulham, interview]

Here we observe the force of standards to render some subjects as more memorable than others. The lack of interoperability that made Matthew's repatriation undecidable positioned him as a specific victim, a victim of non-domestic terrorism. As such, when compared to domestic victims, he is threatened with being eclipsed by the memorial force of events in "our back yard". This understandably was a source of some hurt for Peter and his family. In response to this the family pursued their own independent memorial practices (see Allen, 2014: 85), which afforded them with a more substantial platform for working upon their subjective relations with themselves and others.

The final data sequence features Rachel North, survivor of the London bombings, who was injured in the attack near Kings Cross Station; she subsequently played an instrumental role in organising an informal group of activist survivors. In the first extract she explicitly registers her feelings toward embodying a victim subjectivity: 
You don't want to be disempowered like a victim, OK, I am technically a victim [Rachel North, interview]

Rachel is reluctant to think of herself as a victim of the London bombings although she concedes to being "technically a victim". Identifying a "technical" victimhood raises the possibility of becoming a parallel non-technical subject that can become more than a "disempowered victim". Rachel's remarks here bear the effects of the compensation process and its standard application form, which tended to 'dividualise' and corrode the internal integrity of individual experience. To claim compensation Rachel needed to negotiate the standard claim form in such a way that 'technically 'presented herself as a victim. This exposes Rachel's subjectivity to the weight of victimhood discourses, which have a long and complex history in Western episodes of violent conflict. There have been occasions throughout history when constructing a victim subjectivity was politically advantageous, however victimhood has also been subject to the effects of the radical ambiguity that define states of exception. In the extract above we observe Rachel managing issues of empowerment and subjectivity. Differentiating between a technical victimhood and nontechnical subjectivity works to negate the radically ambiguous victim-perpetrator dichotomy of criminal justice and furnished Rachel with the discursive terms to engage in subjective relations according to her own preferred story. This framed relations with others when a small number of survivors founded an informal group. In the next extract Rachel outlines the role of the group known to its members as Kings Cross United and describes their intersubjective relation to a terrorist subjectivity:

[Survivors] kept in contact with each other on a daily or weekly basis through periodic pub meetings organised every 2, 3, 4 weeks, moving to once a month, once a quarter, and they still go on... It was also partly, you know, fuck you terrorists you're not going to provoke this response. We used to say when we met, fuck you Al Qaeda, you thought you were going to cause massive divisions of hate and problems and people become polarised, you know, ha ha, we're all in the pub together. [Rachel North, interview]

It is tempting to read the self-organising practices of Kings Cross United through the framework of governmentality, outwardly it would seem that even without a sovereign injunction to do so survivors sought confessional practices to govern themselves. But we argue, in a state of exception, these humble pub gatherings afforded more to survivors than internalising the governing role of sovereignty. There is a long tradition of organising similar grassroots support-style groups around experiences of extreme violence. For instance Alcoff and Grey (1993) discussed the "speak outs", organised by activist networks of sexual abuse survivors, in which participants made public disclosures about their experiences of sexual violence. The authors argue that such meetings could host subversive and recuperative discourse so long as "experts" were eliminated as central mediators; a psychiatrist or legal practitioner is to speak outs what the priest was to Christian confession. Evidently the group functioned as a way "to meet up with others who were there too." In the absence of a state apparatus for converting dividual matters, such as injury, grief and guilt, into clear subjective states, meeting up presented the opportunity to engage with one another as whole subjects rather than as desubjectified parts of the terrorist incident. Through Kings Cross United the issue of case-worthiness was collectivised, that is made transindividual, as members 
participated in each other's subjective work of becoming a life beyond technical victimhood. On the basis of such a collaborative work survivor discourse can be enfranchised to the status of what Foucault called 'veridiction', that is a statement that holds true for the worldview of certain subjects, hence collectively Kings Cross United could produce a subversive, and perhaps recuperative, discourse ("fuck you terrorists... fuck you Al Qaeda") about which the anchor in truthfulness lies in the usefulness of the statement in supporting a conclusive work of self-making. So it is in the pub, and not the compensation claim form, throughout the course of performing their relationships to themselves as survivors and to an unspecified enemy their "informal arrangement" addressed the "desubjectifying" effects of undecidability that the members must face elsewhere in their lives.

\section{Cranked Subjects (a conclusion)}

The standards that exist for compensating victims of terrorism are messy social processes that position and modulate the routes through which victims and their relatives can engage in projects of self-making that enable some sense to made of injury and loss. However, the formulation and application of these standards tends to act as an obstacle to the reconstruction of the victim as a whole, political subject. In this sense, compensation practices act as a technology of desubjectification. In part this arises because the historical formation of the legal aspects of compensation in the UK have drawn mainly upon the codes of retributive rather than restorative justice. But the mobilisation of these standards reflects, we argue, the wider 'state of exception' that characterises the operation of the modern state. Persons who are caught up in incidents of terrorism are refused the status of political subjects, and are instead actively positioned in an elastic and ill-defined 'garbage category' of victimhood for as long as possible in order that the state not 'show its hand' by offering a settlement that may risk according the person the status of a political actor whose views and experiences need to be taken into account.

Whilst our argument has been worked out in relation to this specific example of victims of terrorism, the general points have, we assert, some purchase on the broader relationship between standards and subjectivity that arises from the neoliberal 'biopolitical' vision of the state that is current crystallised in the project of austerity being enacted across numerous European countries. Modern social administration begins, as Foucault tells us, with the masses being differentiated through the development of technologies of subjectification and the associated practices of governance for which Foucault uses the shorthand term 'discipline' (1977). Lives become potential cases, in anticipation of which persons subjectify themselves in relation to overarching norms and standards. But the biopolitical state which settles into a mode of 'austerity', is increasingly unconcerned with producing detailed knowledge of its citizens. It is merely concerned with those 'bits' of people that it can work with - it has no interest in 'individuals' as such, only with the coding of partial attributes of persons, or 'dividual' matter (cf. Deleuze, 1995). To this end, the distributed apparatuses which together compose state power increasingly deploy diffuse categories and flexible standards which keep persons in 'holding patterns' where judgement and intervention is deferred as long as possible. The goal is precisely the reverse of that described by Foucault in Lives of Infamous Men: the sovereign will find every means possible to ignore the 
summons to act, whilst simultaneously encouraging ever more description and transcription of the quotidian. Those who petition the state - in terms of social welfare, mental health, education or justice - find that their efforts to make themselves into subjects are met by strategies that dissolve the specificity of their experiences as a means of deferring their claims upon the state.

The image of the panopticon therefore needs to be replaced with one that captures the experience of being dedifferentiated and desubjectified. Foucault's interest in the 'classical era' of disciplinary techniques points the way towards just such an image. At around the time that Jeremy Bentham envisaged the 'impossible prison' design of the panopticon, a more mundane technology was being deployed in British penal institutions. The 'crank' is a small piece of machinery that typically took the form of a box with a rotating handle.

Prisoners were required to turn this handle for either a set period of time or specified number of turns. Prison officers could adjust the resistance of the handle through tightening or loosening internal screws (giving rise to the colloquial British term for guards as 'screws'). But the crank itself was not connected to any outside machinery. The turning of the handle served no other purpose than to demonstrate that the prisoner was complying with the standards that were being enforced. The inmate turns the crank, whilst knowing full well the futility of doing so, in the hope that if they can be seen to have complied as fully as possible, some other future might be possible.

Here is a model for modern desubjectification: 'cranked subjects' for whom subjectivity is held in extended state of suspension. Critical psychology has been concerned for so long now with the corrosive effects of the institutional practices which comprise the 'psycomplex' on subjectivity. But in reality, the state has no interest in subjects as such. Great swathes of the population find that their engagement with the state consists of repeatedly calling for intervention, whilst finding themselves either moved from one meaningless category to the next whilst failing to arouse the concern of any specific institution, or else of being lodged semi-permanently in a category that allows the state to reserve judgment for as long as possible. We have to recognise that there are worse things than being subjectified. To be knocking on the door of the state, desperate for ones experiences and actions to be taken seriously. And yet, for there to be no reply.... That is the real problem that critical psychology needs to address.

\section{References}

Agamben, G. (1998) Homo Sacer: Sovereign Power and Bare Life. Stanford, CA: University of California Press.

Agamben, G. (2005) State of exception. London: University of Chicago Press.

Alcoff, L., and Gray, L. (1993) 'Survivor Discourse : Transgression or Recuperation?', Signs, Vol. 18(2), pp.260-290. 
Allen, M.J., and A Bryan (2011) 'Editorial: Remembering the 2005 London bombings: Media, memory, commemoration', Memory Studies, Vol. 4(3), pp. 263-268.

Allen, M. (2014) The labour of memory: Memorial culture and 7/7. London: Palgrave Macmillan.

Anderson, B. (2010) 'Security and the future: Anticipating the event of terror', Geoforum, 41(2), 227-235.

Ashworth, A. (2005) Sentencing and Criminal Justice. Cambridge University Press.

Bartrip, P. and Burman, S. (1984) The Wounded Soldiers of Industry: Industrial Compensation Policy, 1833-97. Oxford: Clarendon Press.

BBC (2010) 'Victim payouts to be reviewed after 7/7 London bombs', 19 October, BBC News, accessed online at: http://www.bbc.co.uk/news/uk-11576478

Bennett, C. (2006) 'Why have the 7/7 victims received such pitiful compensation? Where are the celebrity charity fundraisers for them?', The Guardian, 6 July, accessed online at: http://www.theguardian.com/commentisfree/2006/jul/06/comment.july7

Bossong, R. (2013) The Evolution of EU Counter-terrorism: European Security Policy After 9/11. Abingdon, Oxon: Routledge.

Bottigliero, I. (2012) 'Realizing the right to redress for victims of terrorist attacks', in de Frías, A. M. S., Samuel, K., and White, N. (Eds.) Counter-Terrorism: International Law and Practice. Oxford: Oxford University Press. pp. 908-935.

Bowker, G. C., and Star, S. L. (1999) Sorting Things Out: Classification and Its Consequences. Cambridge, MA: MIT Press.

Bowker, G. C., and Star, S. L. (2000) 'Invisible Mediators of Action: Classification and the Ubiquity of Standards', Mind, Culture, and Activity, 7(1-2), 147-163.

Burnham, J. (2010) Accident Prone: A History of Technology, Psychology, and Misfits of the Machine Age. London: University of Chicago Press.

Butler, J. (2009) Frames of War: When is Life Grievable? London: Verso.

Buzan, B. (2003) 'Implications for the study of international relations', in Buckley, M. and Fawn, R. (Eds.) Global responses to terrorism: 9/11, Afghanistan and beyond. London: Routledge. pp. 296-309.

Chomsky, N. (2002) Pirates and Emperors, Old and New: International Terrorism in the Real World. Boston: South End Press. 
Clough, P., and Willse, C. (2011) Beyond biopolitics: essays on the governance of life and death. Durham, North Carolina: Duke University Press.

Cox, M. (2002) 'American Power Before and After 11 September: Dizzy with Success', International Affairs, 78(2), 261-276.

Cromby, J. and Willis, M. (2014) 'Nudging into Subjectification: Governmentality and Psychometrics', Critical Social Policy, Vol. 34(2), pp. 241-259.

Cromby, J., Harper, D. and Reavey, P. (2013) Psychology, Mental Health and Distress. London: Palgrave.

Dean, M. (2010) The Constitution of Poverty:Toward a genealogy of liberal governance. London: Routledge.

Dean, M. (2013) The Signature of Power: Sovereignty, Governmentality and Biopolitics. London: Sage.

Deleuze, G. (1995) Negotiations. Joughin, M. (Trans). New York: Columbia University Press.

Dillon, M. (2007) 'Governing Terror : The State of Emergency of Biopolitical Emergence', International Political Sociology, 1, 7-28.

Fisher, J. P., and Flota, B. (2013) The Politics of Post-9/11 Music: Sound, Trauma, and the Music Industry in the Time of Terror: Sound Trauma and the Music Industry. Farnham, Surrey: Ashgate Publishing, Limited.

Foucault, M. (1977) Discipline and Punish: The Birth of the Prison. Trans. Sheridan A. New York: Vintage Books.

Foucault, M. (Ed) (1978) I Pierre Riviere, Having Slaughtered My Mother, My Sister, and My Brother: A Case of Parricide in the Nineteenth Century. London: Penguin.

Foucault, M. (1988) Hercule Barbin: Being the Recently Discovered Memoirs of a Nineteenth Century Hermaphrodite. New York: Random House.

Foucault, M. (2002) The Lives of Infamous Men. In Power: Essential works of Foucault 19541984, vol. 3. London: Allen Lane, pp. 157-175.

Gillard, E. (2003) 'Reparations for Violations of International Humanitarian Law', International Review of the Red Cross, 851, 529-554.

Graeber, D. (2011) Debt: The first 5000 years. Brooklyn, NY: First Melville House Printing.

Guyton G. (1999) 'A brief history of workers' compensation', lowa Orthop Journal, 19, 106110.

Hanna, P. (2013) 'Reconceptualizing subjectivity in critical social psychology: Turning to Foucault', Theory \& Psychology, 23(5), 657-674. 
Harrington, R. (2001) 'The Railway Accident: Trains, Trauma, and Technological Crises in Nineteenth-Century Britain', in Micale, M.S. and Lerner, P. (Eds.) Traumatic Pasts: History, Psychiatry, and Trauma in the Modern Age, 1870-1930. Cambridge: Cambridge University Press. 31-56.

Henriques, J., Hollway, W., Venn, C., Walkerdine V., and Urwin, C. (1984) Changing the subject: Psychology, social regulation andsubjectivity. London: Methuen.

Hojgaard, L., and Sondergaard, D. M. (2011) 'Theorizing the complexities of discursive and material subjectivity: Agential realism and poststructural analyses', Theory \& Psychology, 21(3), 338-354.

Hoskins, A., and O'Loughlin, B. (2009) Television and Terror: Conflicting Times and the Crisis of News Discourse. Basingstoke: Palgrave Macmillan.

Hoskins, A., and O'Loughlin, B. (2013) War and Media: The emergence of diffused war. Cambridge: Polity.

Imre, R. (2013) Responding to Terrorism: Political, Philosophical and Legal Perspectives. Aldershot, Hampshire: Ashgate Publishing, Limited.

Kress, G. (2009) Multimodality: A Social Semiotic Approach to Contemporary Communication. London: Routledge.

Kunst, M., Popelier, L. \& Varekamp, E., (2014). 'Victim Satisfaction With the Criminal Justice System and Emotional Recovery: A Systematic and Critical Review of the Literature', Trauma, Violence, \& Abuse, Vol. 0(0), pp. 1-23.

Laxminarayan, M. (2014) 'Psychological effects of criminal proceedings through contact with the judge: the moderating effect of legal system structure', Psychology, Crime \& Law, Vol. 20(8), pp.781-797.

Lorenzo-dus, N. \& Bryan, A. (2011) 'Dynamics of memory: Commemorating the 2005 London bombings in British television news', Memory Studies, Vol. 4(3) pp. 281-297.

Mansey, K. (2012) 'Paralympian 7/7 victim slams $£ 8,000$ compensation scheme', The Sunday Times, 2 September, accessed online at:

http://www.thesundaytimes.co.uk/sto/news/uk_news/Olympics/article1117794.ece

Mol, A. (2008) The logic of care: Health and the problem of patient choice. London: Routledge.

Musson, A. (2001) Medieval Law in Context: The Growth of Legal Consciousness from Magna Carta to The Peasants' Revolt. Manchester: Manchester University Press.

Orend, B. (2002) 'Justice after War', Ethics and International Affairs, 16(1), 43-56.

Parker, I. (2007) Revolution in Psychology: Alienation to Emancipation. London: Pluto Press 
(2014) The Crisis in Modern Social Psychology, and how to end it. Abingdon: Routledge.

Puar, J. K. (2007) Terrorist Assemblages: Homonationalism in Queer Times. Durham, NC: Duke University Press.

Randhawa, K. (2012) 'Seven years on: Victims of 7/7 London bombings are still waiting for payouts', London Evening Standard, 21 May, accessed online at: http://www.standard.co.uk/news/london/seven-years-on-victims-of-77-londonbombings-are-still-waiting-for-payouts-7770676.html

Reid, J. (2006) The biopolitics of the war on terror: Life struggles, liberal modernity, and the defence of logistical societies. Manchester: Manchester University Press.

Reid, J. and Jowell, T. (2006) 'Addressing lessons from the emergency response to the 7 July 2005 London bombings: What we learned and what we are doing about it', 22 September 2006, Norwich: Crown.

Rose, N. (1985) The Psychological Complex: Psychology, Politics and Society in England, 1869-1939. London: Routledge.

(1989) Governing the Soul: The Shaping of the Private Self. London: Free Association Books.

Silk, M. (2013) The Cultural Politics of Post-9/11 American Sport: Power, Pedagogy and the Popular. Abingdon, Oxon: Taylor \& Francis.

Simon, L.M.J. (1995). 'A therapeutic jurisprudence approach to the legal processing of domestic violence cases', Psychology, Public Policy and Law, Vol. 1(1), pp. $43-79$.

Terranova, T. (2009) 'Another Life: The Nature of Political Economy in Foucault's Genealogy of Biopolitics', Theory, Culture \& Society, Vol. 26(6), pp. 234-62.

UN (2011) The Criminal Justice Response to Support Victims of Acts of Terrorism. New York: United Nations Office on Drugs and Crime.

Väliaho, P. (2014) Biopolitical screens: Image, Power and the Neoliberal Brain. London: MIT Press.

Walker, C. (2011) Terrorism and the Law. Oxford: Oxford University Press.

Williams, K. (2005) 'State of fear: Britain's 'compensation culture' reviewed', Legal Studies, 25, 499-515.

Wexler, D. B. and Winick, B. (1996) Law in a Therapeutic Key: Developments in Therapeutic Jurisprudence. Durham, North Carolina: Carolina Academic Press.

Willig, C. (1999) Applied Discourse Analysis: Social and Psychological Interventions. Buckingham: Open University Press. 
Wooffitt, R. (2005) Conversation Analysis and Discourse Analysis: A Comparative and Critical Introduction. London: Sage.

Woolgar, S., and Neyland, D. (2013) Mundane Governance: Ontology and Accountability. Oxford: Oxford University Press.

1 Much of this is already foreshadowed in George Canguilheim's magnificent essay 'What is Psychology?. The English translation of this piece initially appeared in the journal Ideology \& Consciousness, whose editorial board included Nikolas Rose along with many of the contributors to Changing the Subject.

2 The project ran from 2007 to 2011 and was supported by the Arts and Humanities Research Council [grant number AH/E002579/1]

3 For the findings of strand 1 see Lorenzo-Dus and Bryan, 2011).

4 See the project website for further information about events: http://www.newmediaecology.net/mediamemory/bombings/Conflicts of memory/ Welcome.html

5 Including the Factory Act 1833, Employers' Liability Act 1880, the Workman's Compensation Act 1897 and the Industrial Accident Act 1901

6 For the 2012 list of injury tariffs see: https://www.gov.uk/government/uploads/system/uploads/attachment data/file/2 43480/9780108512117.pdf

7 The form can be accessed online at https://www.gov.uk/claim-compensationcriminal-injury

8 Publically available on the archive of evidence submitted to the independent coroner's report:

http://webarchive.nationalarchives.gov.uk/20120216072438/http://7julyinquests.i ndependent.gov.uk/evidence/index.htm 